\title{
A standardized protocol for genomic DNA isolation from Terminalia arjuna for genetic diversity analysis
}

\author{
Maryam Sarwat \\ Department of Biotechnology \\ Jamia Hamdard (Hamdard University) \\ New Delhi 110062, India \\ Tel: 0911126059688 \\ Fax: 0911126059663 \\ E-mail: maryam21_7@yahoo.com \\ Madan Singh Negi \\ TERI, India Habitat Center \\ Lodhi Road, New Delhi 110003, India \\ Tel: 0911124682111 \\ Fax: 0911124682144 \\ E-mail: msnegi@teri.res.in \\ Malathi Lakshmikumaran \\ TERI, India Habitat Center \\ Lodhi Road, New Delhi 110003, India \\ Tel: 0911126192243 \\ Fax: 0911126197578 \\ E-mail: malathi@lakshmisri.com
}

\section{Akhilesh Kumar Tyagi}

Department of Plant Molecular Biology

University of Delhi South Campus

Benito Juarez Marg, New Delhi 110021, India

Tel: 0911124113216

Fax: 0911124119430

E-mail: akhilesh@genomeindia.org

\section{Sandip Das}

Department of Biotechnology Jamia Hamdard (Hamdard University)

New Delhi 110062, India

Tel: 0911126059688

Fax: 0911126059663

E-mail: sdas@jamiahamdard.ac.in

\section{Prem Shankar Srivastava*}

Department of Biotechnology Jamia Hamdard (Hamdard University) New Delhi 110062, India

Tel: 00911126059688 ext 5582

Fax: 00911126059663

E-mail:pss410@rediffmail.com

Financial support: Department of Biotechnology, Govt. of India.

Keywords: DNA extraction, medicinal plants, molecular markers, Terminalia species.

Abbreviations: AFLP: amplified fragment length polymorphism

RAPD: random amplification of polymorphic DNA

ISSR: inter simple sequence repeats

For studying genetic diversity in natural populations of Terminalia, a medicinal plant, our attempts to isolate high quality DNA using several previously reported protocols and even modifications were unsuccessful. We

* Corresponding author 
therefore combined CTAB based isolation, and column based purification step, to isolate DNA from Terminalia arjuna. The DNA isolated using this standardized protocol was high in quality and suitable for restriction digestion and generation of random amplification of polymorphic DNA (RAPD) and amplified fragment length polymorphism (AFLP).

Among the nearly 15,000 flowering plants documented, many of them are used as sources of medicine. In the developing nations, almost $80 \%$ people depend on these plants for medicine because of their easy availability and low cost of treatment. The modern allopathic system of medicine is known to produce serious side-effects and resistance against antibiotics which make these drugs nonpotent (Pirttila et al. 2001). Terminalia arjuna is one of the plants which holds a reputed position in both Ayurvedic and Unani Systems of medicine. According to Ayurveda, it is alexteric, styptic, tonic, anthelmintic and useful in treatment of fractures, ulcers, heart diseases, biliousness, urinary discharges, asthma, tumours, leucoderma, anaemia, excessive perspiration etc. In Unani System, it is used both externally and internally in problems related to urinary discharges. It also serves as expectorant, aphrodisiac, tonic and diuretic. Its bark is reported to be useful in the treatment of coronary artery diseases, heart failure, hypercholestrolemia and anginal pain (Miller, 1998). The cardioprotective nature has also been described by Karthikeyan et al. (2003) and its antiviral activity (against HSV-2) by Cheng et al. (2002). The plant has potential antibacterial activity against Escherichia coli, Klebsiella aerogenes, Proteus vulgaris, Pseudomonas aeruginosa (Perumal et al. 1998), multi-drug resistant Salmonella typhi (Rani and Khullar, 2004), and also shows antimutagenic activity (Scassellati-Sforzolini et al. 1999).

There is no information available on the existing germplasm diversity in Terminalia arjuna and, therefore, cataloguing of natural genetic diversity becomes essential for its efficient and sustainable germplasm management. DNA based assays such as RAPD and AFLP are the most widely used tools for assessment of the genetic variation (Singh et al. 1999; Belaj et al. 2002; Shan et al. 2005). Isolation of purified DNA, for such an exercise, from medicinal plants is challenging because of secondary metabolites and other compounds. A large number of secondary metabolites such as tannins, alkaloids, phenolics and terpenes responsible for the valuable pharmacokinetic properties of medicinal plants interfere with the isolation process, tend to copurify with DNA and interact irreversibly with proteins and nucleic acids (Katterman and Shattuck, 1983). For characterization of germplasm of Terminalia arjuna, T. bellerica and T. chebula, isolation of purified DNA proved to be a major bottleneck, especially in case of T. arjuna, as has also been experienced with other species like Theobroma cacao (Haymes et al. 2004), Vitis vinifera (Hanania et al. 2004), Pinus radiata (Crowley et al. 2003), Tagetes minuta (Hills and van Staden, 2002)
Eucalyptus spp., Pinus spp. and Araucaria cunninghamii (Shepherd et al. 2002), Davidia involuctata (Li et al. 2002) Anthurium andreanum (Buldewo and Jaufeerally-Fakim, 2002), Drosera rotundifolia, Artemisia dracunculus (Pirttila et al. 2001).

We attempted a dozen of previously reported and also modified protocols but the dirty yellow and highly viscous DNA obtained was not suitable for manipulation and analysis. The aim of this study was to establish a new protocol for DNA isolation from Terminalia arjuna plants to get high quality DNA that is suitable for generation of molecular markers, such as RAPD and AFLP.

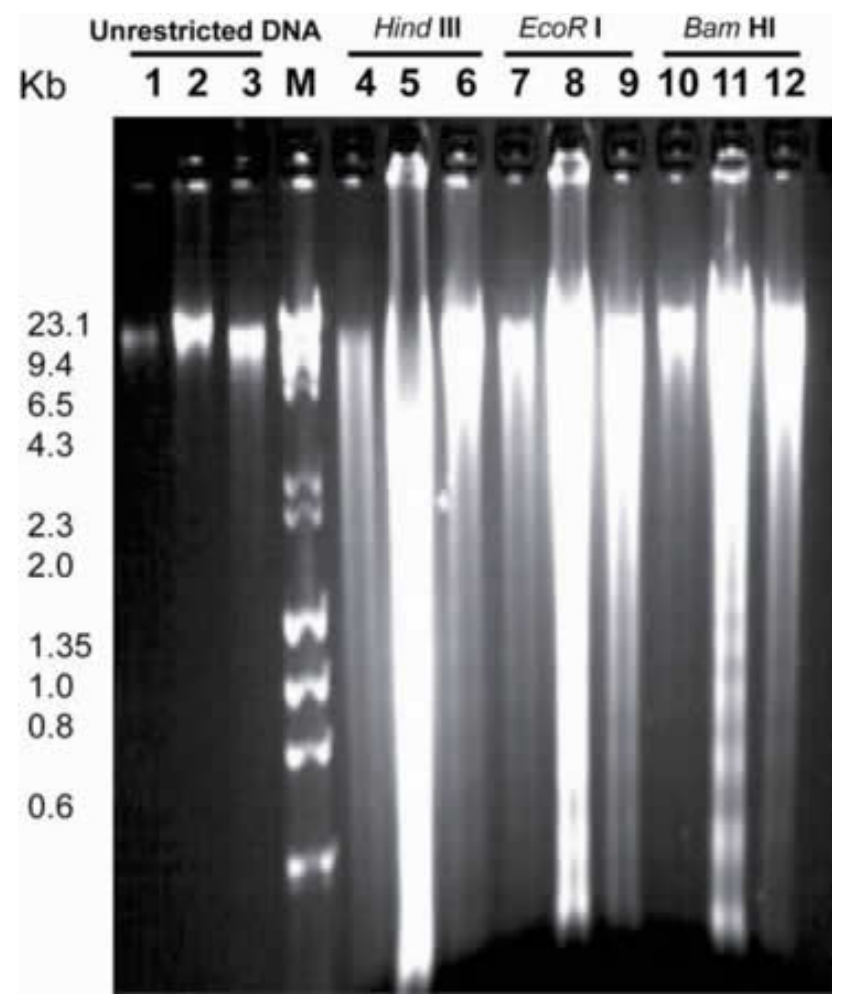

Figure 1. Restriction pattern of DNA isolated following modified protocol. Two $\mu \mathrm{g}$ of genomic DNA from Terminalia arjuna, $T$. bellerica and $T$. chebula were loaded either undigested (lanes 1, 2, 3, respectively) or after Hind III (lanes 4, 5, 6, respectively), Eco RI (lanes 7, 8, 9, respectively) and Bam $\mathrm{HI}$ (lanes 10, 11, 12, respectively) digestion. A mixture of $\lambda$ DNA digested with Hind III and $\varphi$ X174 DNA digested with Hae III was loaded as marker (lane M).

\section{MATERIALS AND METHODS}

Material Collection: Juvenile leaves collected from different geographical regions of natural populations of Terminalia arjuna were stored on dry ice, lyophilized using standard procedure and stored at $-20^{\circ} \mathrm{C}$ till DNA isolation. DNA isolation was carried out within 7-10 days to avoid degradation.

\section{DNA isolation}

Only the successful procedure of DNA isolation along with 
the modifications that were carried out and purification is reported here. The DNA isolated by CTAB method (Doyle and Doyle, 1990) was dissolved in $1 \mathrm{ml}$ of sterile double distilled water (DDW) and purified using a column (Genelute plant genomic DNA extraction kit- G2N 70, Sigma Aldrich).

\section{Solutions and solvents}

- CTAB Buffer (1.4M NaCl, 100 mM Tris- $\mathrm{HCl}$ pH 8.0, $20 \mathrm{mM}$ EDTA $\mathrm{pH}$ 8.0, 2\% CTAB; added $\beta$ mercaptoethanol before use).

- Chloroform: IsoAmyl alcohol (24:1).

- Isopropanol.

- Ethanol $70 \%$ and $96 \%$.

The details of procedure are given below:

- Mix $700 \mu$ of the binding solution provided in the kit with the dissolved DNA $(1 \mathrm{ml})$.

- Take $700 \mu 1$ of the above solution in a "red-o-ringed" column fitted in a $2 \mathrm{ml}$ collection tube.

- Centrifuge at $12000 \mathrm{~g}$ for $1 \mathrm{~min}$.

- Discard the flow-through liquid, add the remaining solution to the same column.

- Centrifuge at $12000 \mathrm{~g}$ for $1 \mathrm{~min}$.

- Discard the flow-through liquid along with the collection tube and transfer the column to a new $2 \mathrm{ml}$ collection tube.

- Add $500 \mu 1$ of the Washing Buffer (diluted with ethanol) to the column and centrifuge as above.

- Again discard the flow-through liquid, repeat the washing and centrifugation steps.

- Discard the flow-through liquid as well as the collection tube and fix the column to a new $2 \mathrm{ml}$ collection tube.

- Add $100 \mu \mathrm{l}$ of Elution Buffer (pre-heated at $65^{\circ} \mathrm{C}$ ) to the column. Centrifuge as above. This is first eluate of DNA. Transfer the column to a fresh collection tube and elute as above. This is second eluate.

- To test effectiveness and efficiency of this protocol, we restricted the DNA with commonly used restriction enzymes and also tried generation of RAPD and AFLP markers.

\section{Restriction digestion}

Two to three mg of genomic DNA was digested overnight with 10 units of restriction enzymes under optimal temperature and buffer following manufacturers recommendation (Bangalore Genei, India). The digested DNA was electrophoresed on $0.8 \%$ agarose at $5 \mathrm{~V} / \mathrm{cm}$ along with undigested DNA as control.

\section{RAPD analysis}

RAPD analysis was performed in a $15 \mu$ l volume of reaction mixture containing $1 \mathrm{X}$ Taq Polymerase Buffer (with $25 \mathrm{mM} \mathrm{MgCl}_{2}$ ), 0.6 units of Taq DNA Polymerase (Bangalore Genei, India), $5 \mathrm{mM}$ dNTPs (MBI Fermentas), $10 \mathrm{mM}$ of random decamer primer (Finnzymes) and $15 \mathrm{ng}$ of total genomic DNA. Amplifications were carried out using a DNA thermal cycler (Mastercycler gradient, Eppendorf) with the following parameters: One cycle at $94^{\circ} \mathrm{C}$ for $2 \mathrm{~min}, 36^{\circ} \mathrm{C}$ for $2 \mathrm{~min}$ and extension at $72^{\circ} \mathrm{C}$ for 2 min; 29 cycles of denaturation at $94^{\circ} \mathrm{C}$ for $1 \mathrm{~min}$, primer annealing at $36^{\circ} \mathrm{C}$ for $1 \mathrm{~min}$ and extension at $72^{\circ} \mathrm{C}$ for 1 min; and final extension at $72^{\circ} \mathrm{C}$ for $10 \mathrm{~min}$. The reaction was stored at $8^{\circ} \mathrm{C}$ till loaded on gel. The products were size fractionated on $1.2 \%$ agarose gel and visualized under UV light after ethidium bromide staining.

\section{AFLP analysis}

Genomic DNA (300-500 ng) was digested to completion with Eco RI + Mse I. After heat inactivation, an aliquot was ligated to Eco RI and Mse I specific adapters at $20^{\circ} \mathrm{C}$ overnight. The adapter ligated DNA was preamplified using Eco RI and Mse I pre-amplification oligos with oneselective nucleotide. The pre-amplified library was diluted with sterile water in a ratio of 1:50. Selective amplification was carried out using $\gamma$ - $\mathrm{P}^{32}$-ATP labelled Eco RI oligo in combination with Mse I oligo, each with 3 selective nucleotides at the 3 ' end. Equal volume of formamide dye was added to the amplified products and electrophoresed on $6 \%$ PAGE under denaturing conditions and then autoradiographed (Sambrook et al. 2001).

\section{Delhi Dehradun Chennai Mysore Udaipur Agra}
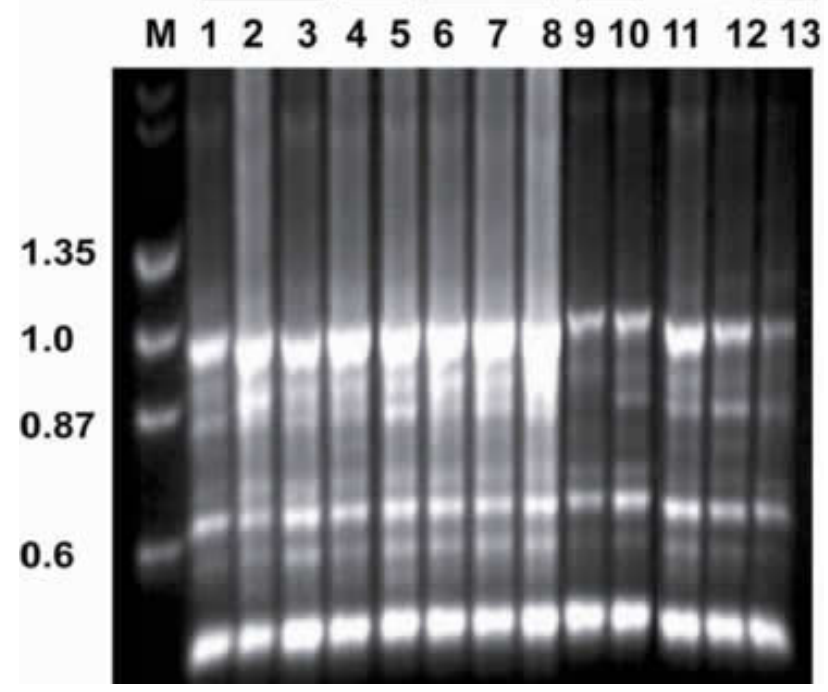

Figure 2. RAPD profile of $T$. arjuna generated by the primer OPA-02 (5'TGCCGAGCTG3'). The samples were collected from different parts of India (as indicated above the lanes). A mixture of $\lambda$ DNA digested with Hind III and $\varphi$ X174 DNA digested with Hae III was loaded as marker (lane M).

\section{RESULTS AND DISCUSSION}

Published methods of DNA isolation including those of Doyle and Doyle (1990), Rogers and Benedich (1985) and Dellaporta et al. (1983) proved unsuccessful and unreliable 
for T. arjuna as the DNA obtained was dirty yellow in appearance and with high viscosity. This may be due to high endogenous levels of polysaccharides, phenolics and other organic constituents that interfere with DNA isolation and purification. The isolated DNA could not be subjected to even agarose gel electrophoresis.

In higher plant tissues, particularly in medicinal plants, these secondary compounds generally get accumulated and the problem becomes severe as the material gets older. Polysaccharide contaminations are particularly problematic (Scott and Playford, 1996) as they can inhibit the activity of many commonly used molecular biological enzymes, such as polymerases (Fang et al. 1992), ligases and restriction endonucleases. This is because nucleic acids form tight complexes with polysaccharides creating a gelatinous pellet and the embedded DNA is inaccessible to the enzymes (Sharma et al. 2002). Polyphenol contamination of DNA makes it resistant to restriction enzymes as also shown in other taxa where polyphenol copurify with DNA (Katterman and Shattuck, 1983) and interact irreversibly with proteins and nucleic acids (Loomis, 1974). This phenomenon is mainly due to the oxidation of polyphenols to quinones by polyphenol oxidase followed by covalent coupling or by oxidation of the proteins by the quinines. During homogenization, polyphenols are released from vacuoles and they then react rapidly with cytoplasmic enzymes. DNA isolation protocols generally use CTAB to avoid co-purifying polysaccharides from plant tissues. Keeping this in mind and the fact that $T$. arjuna samples carry high amounts of polysaccharides, we tried the standard CTAB method (Doyle and Doyle, 1990) and also several modifications including increase in the concentration of CTAB to $2.5 \%$ (Khanuja et al. 1999), $\beta$ mercaptoethanol to $1 \%$ (Tel-zur et al. 1999), and $\mathrm{NaCl}$ to 2.2 M (Aljanabi et al. 1999). Other alterations tried include replacing CTAB with SDS (Keb Llanes et al. 2002) and sarcosyl (Sharma et al. 2002). Polyvinylpyrrolidone (PVP, MW 40,000) has also been successfully used to sequester or remove polyphenols. Since leaves of Terminalia are rich in polyphenols, we tried different percentages of PVP, 1, 2, and 4 as also proposed by others (1\%, Khanuja et al. 1999; 2\%, Dellaporta et al. 1993, and Csaikl et al. 1998; and 4\%, Keb Llanes et al. 2002). These modifications were tried either alone or in combinations but the DNA yield remained unsatisfactory in terms of quality, restrictability and amplifiability. The only modification that proved successful was when CTAB based isolation was combined with column-based purification. The existing CTAB protocol for DNA isolation was further extended by incorporating an additional final step of purifiation based on Gen Elute (Sigma). Either of the protocols, CTAB or Gen-Elute did not succeed in overcoming the problem of low quality and quantity of DNA when used as a standalone procedure. In the CTAB-column based procedure, the DNA first binds to the column helping washing of the impurities in the flow-through liquid. The column bound DNA is washed twice with washing buffer and the pure DNA is then eluted with elution buffer. The total DNA yield was approximately $10-15 \mu \mathrm{g}$ from $200 \mathrm{mg}$ freezedried tissue.

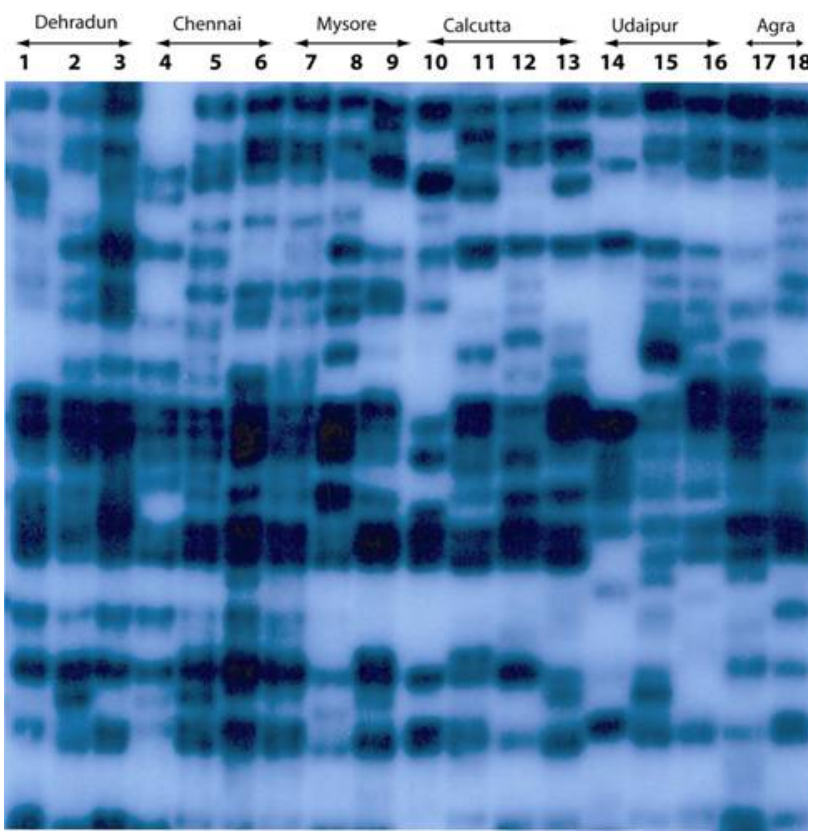

Figure 3. AFLP analysis of $T$. arjuna using selective primer combination E-AAG + M-CAG. The different lanes correspond to samples from Dehradun (1-3), Chennai (4-6), Mysore (7-9), Calcutta (10-13), Udaipur (14-16) and Agra (17-18).

The purity was evident when the DNA was restricted with Hind III, Eco RI and Bam HI (Figure 1). As a further test, we performed RAPD analysis using several primers. One such effort is shown in Figure 2. Primer A-02 amplified seven monomorphic bands but other primers have yielded polymorphic products both at inter-zonal and intra-zonal levels (data not shown). AFLP results are shown in Figure 3. Selective amplification of Terminalia arjuna DNA isolated following our modified protocol was carried out using a primer combination of Eco RI - AAG + Mse I CAG. Several monomorphic and polymorphic products could be observed upon autoradiography (Figure 3 ). We are carrying out further work to generate data to calculate and catalogue the genetic diversity using both RAPD and AFLP.

We have thus established a reliable method for isolation of good quality DNA from $T$. arjuna, a problem tree material for DNA isolation, that is amenable to both restriction, and PCR based analyses such as RAPD and AFLP. The data demonstrate that the method devised by us yields highly purified DNA, which is transparent, non-sticky and has no visible RNA contamination when electrophoresed on agarose gel. The samples are amenable to restriction digestion by Eco RI, Bam HI and Hind III restriction enzymes.

In conclusion, extraction of DNA from Terminalia arjuna is difficult owing to the presence of large amount of secondary metabolites and polyphenols. We could 
circumvent this by combining the CTAB method with a column-based purification process. This could be adopted as a standard method for the tree species, T. arjuna, T. bellerica and $T$. chebula and other trees for isolation of DNA for RAPD, ISSR and AFLP analyses.

\section{REFERENCES}

ALJANABI, S.M.; FORGET, L. and DOOKUN, A. An improved and rapid protocol for the isolation of polysaccharide and polyphenol free sugarcane DNA. Plant Molecular Biology Reporter, September 1999, vol. 17, no. 3, p. 281.

BELAJ, A.; SATOVIC, Z.; RALLO, L. and TRUJILLO, I. Genetic diversity and relationships in olive (Olea europaea L.) germplasm collections as determined by randomly amplified polymorphic DNA. Theoretical and Applied Genetics, September 2002, vol. 105, no. 4, p. 638-644.

BULDEWO, S. and JAUFEERALLY-FAKIM, Y.F. Isolation of clean and PCR-amplifiable DNA from Anthurium andreanum. Plant Molecular Biology Reporter, March 2002, vol. 20, no. 1, p. 71a-71g.

CHENG, H.Y.; LIN, C.C. and LIN, T.C. Antiherpes simplex virus type 2 activity of casuarinin from the bark of Terminalia arjuna Linn. Antiviral Research, 2002, vol. 55, no. 3, p. 447-455.

CROWLEY, T.M.; MURALITHARAN, M.S. and STEVENSON, T.W. Isolating conifer DNA: a superior polysaccharide elimination method. Plant Molecular Biology Reporter, March 2003, vol. 21, no. 1, p. 97a-97d.

CSAIKL, U.M.; BASTIAN, M.; BRETTSCHNEIDER, R.; GAUCH, S.; MEIR, A.; SCHAUERTE, M.; SCHOLZ, F.; SPERISEN, C.; VORNAM, B. and ZIEGENHAGEN, B. Comparative analysis of different DNA extraction protocols: A fast universal maxi preparation of high quality plant DNA for genetic evaluation and phylogenetic studies. Plant Molecular Biology Reporter, March 1998, vol. 16, no. 1, p. 69-86.

DELLAPORTA, S.L.; WOOD, J. and HICKS, J.B. A plant DNA minipreparation: version II. Plant Molecular Biology Reporter, March 1983, vol. 1, no. 1, p. 19-21.

DOYLE, J.J and DOYLE J.L. Isolation of plant DNA from fresh tissue. Focus 1990, vol. 12, no. 1, p. 13-15.

FANG, G.; HAMMER, S. and GRUMET, R. A quick and inexpensive method for removing polysaccharides from plant genomic DNA. Biotechniques, 1992, vol. 13, no. 1, p. 52-54.

HANANIA, U.; VELCHEVA, M.; SAHAR, N. and PERL, A. An improved method for isolating high-quality DNA from Vitis vinifera nuclei. Plant Molecular Biology Reporter, June 2004, vol. 22, no. 2, p. 173-177.
HAYMES, K.M.; IBRAHIM, I.A.; MISCHKE, S.; SCOTT, D.L. and SAUNDERS, J.A. Rapid isolation of DNA from chocolate and date palm tree crops. Journal of Agricultural Food Chemistry, 2004, vol. 52, no. 17, p. 5456-5462.

HILLS, P. N. and VAN STADEN, J. An improved DNA extraction procedure for plant tissues with a high phenolic content. South African Journal of Botany, December 2002, vol. 68 , no. 4 , p. $549-550$.

KARTHIKEYAN, K.; BAI, B.R.; GAUTHAMAN, K.; SATHISH, K.S. and DEVARAJ, S.N. Cardioprotective effect of the alcoholic extract of Terminalia arjuna bark in an in vivo model of myocardial ischemic reperfusion injury. Life Science, 2003, vol. 73, no. 1, p. 2727-2739.

KATTERMAN, F.R.H. and SHATTUCK, V.I. An effective method of DNA isolation from the mature leaves of Gossypium species that contain large amounts of phenolics, terpeniodes and tannins. Preparative Biochemistry, 1983, vol. 13, p. 347-359.

KEB LLANES, M.; GONZALEZ, G.; CHIMANZANERO, B. and INFANTE, D. A rapid and simple method for small scale DNA extraction in Agavaceae and other tropical plants. Plant Molecular Biology Reporter, September 2002, vol. 20, no. 3, p. 299a-299e.

KHANUJA, S.P.S.; SHASANY, A.K.; DAROKAR, M.P. and KUMAR, S. Rapid isolation of DNA from dry and fresh samples of plants producing large amounts of secondary metabolites and essential oil. Plant Molecular Biology Reporter, March 1999, vol. 17, no. 1, p. 74.

LI, Y.X.; SU, Z.X. and CHEN, F. Rapid extraction of genomic DNA from leaves and bracts of dove tree (Davidia involucrata). Plant Molecular Biology Reporter, June 2002, vol. 20 , no. 2 , p. $185 \mathrm{a}-185$ e.

LOOMIS, W.D. Overcoming problems of phenolics and quinones in the isolation of plant enzymes and organelles. Methods in Enzymology, 1974, vol. 31, p. 528-545.

MILLER, Alan L. Botanical influences on cardiovascular disease. Alternative Medicine Review, December 1998, vol. 3 , no. 6 , p. $422-431$.

PERUMAL, S.R.; IGNACIMUTHU, S. and SEN, A. Screening of 34 Indian medicinal plants for antibacterial properties. Journal of Ethnopharmacology, September 1998, vol. 62, no. 2, p. 173-181.

PIRTTILA, A.M.; HIRSIKORPI, M.; KAMARAINEN, T.; JAAKOLA, L. and HOHTOLA, A. DNA isolation methods for medicinal and aromatic plants. Plant Molecular Biology Reporter, September 2001, vol. 19, no. 3, p. 273a-273f.

RANI, P. and KHULLAR, N. Antimicrobial evaluation of some medicinal plants for their anti-enteric potential 
against multi-drug resistant Salmonella typhi. Phytotherapy Research, August 2004, vol. 18, no. 8, p. 670-673.

ROGERS, S.O. and BENEDICH, A.J. Extraction of DNA from milligram amounts of fresh, herbarium and mummified plant tissues. Plant Molecular Biology, 1985, vol. 5 , no 2, p. 69-76.

SAMBROOK, J.; MACCALLUM, P. and RUSSELL, D. Molecular Cloning: A Laboratory Manual. $3^{\text {rd }}$. Cold Spring Harbor Press, NY, 2001. 2344 p. ISBN 0-87969-577-3.

SCASSELLATI-SFORZOLINI， G.; VILLARINI， L.M.; MORETTI, L.M.; MARCARELLI, L.M.; PASQUINI, R.; FATIGONI, C.; KAUR, L.S.; KUMAR, S. and GROVER, I.S. Antigenotoxic properties of Terminalia arjuna bark extracts. Journal of Environment Pathology, Toxicology and Oncology, 1999, vol. 18, no. 2, p. 119-125.

SCOTT, K.D. and PLAYFORD, J. DNA extraction technique for PCR in rain forest plant species. Biotechniques, June 1996, vol. 20, no. 6, p. 974-978.

SHAN, F.; CLARKE, H.C.; PLUMMER, J.A.; YAN, G. and SIDDIQUE, K.H.M. Geographical patterns of genetic variation in the world collections of wild annual Cicer characterized by amplified fragment length polymorphisms. Theoretical and Applied Genetics, January 2005, vol. 110, no. 2, p. 381-391.

SHARMA, A.D.; GILL, P.K. and SINGH, P. DNA isolation from dry and fresh samples of polysaccharide-rich plants. Plant Molecular Biology Reporter, December 2002, vol. 20 , no. 4, p. 415a-415f.

SHEPHERD, M.; CROSS, M.; STOKOE, R.L.; SCOTT, L.J. and JONES, M.E. High-throughput DNA extraction from forest trees. Plant Molecular Biology Reporter, December 2002, vol. 20, no. 4, p. 425a-425j.

SINGH, A.; NEGI, M.S.; RAJAGOPAL, J.; BHATIA, S.; TOMAR, U.K.; SRIVASTAVA, P. S. and LAKSHMIKUMARAN, M. Assessment of genetic diversity in Azadirachta indica using AFLP markers. Theoretical and Applied Genetics, July 1999, vol. 99, no. 12, p. 272-279.

TEL-ZUR, N.; ABBO, S.; MYLABOSKI, D. and MIZRAHI, Y. Modified CTAB procedure for DNA isolation from epiphytic cacti of the genus Hylocereus and Selenicerus (Cactaceae). Plant Molecular Biology Reporter, September 1999, vol. 17, no. 3, p. 249-254. 